produced confirmatory evidence. ${ }^{7}$ The relevance of endometrial fibrinolysis to IUD menorrhagia was suggested by finding high fibrinolytic activity around IUDs removed from women with excessive bleeding. ${ }^{8}$ The use of EACA in the treatment of IUD menorrhagia therefore has a rational basis. Our results show that EACA reduces menstrual blood loss in women using IUDs. This effect is limited to the days of treatment and no carry-over to the next period was found. The duration of periods does not appear to be affected. A steady rise in the menstrual loss during treatment periods appeared to be due to failure to maintain adequate dosage in successive periods.

We concluded that EACA is effective in controlling IUD menorrhagia and that intermenstrual bleeding is reduced.

We thank Mr John Guillebaud for co-operation. We are grateful to Miss E Thomas and Mrs G Guillebaud for nursing help, and to Misses E Johnston, D Ayres, and G Danks for technical work.

This study was made possible by financial help from the Ford
Foundation, the International Planned Parenthood Federation, and the University of Zambia. KABI supplied the EACA and supported Miss Jihnston. Sanitary materials were supplied by Lilia-White Ltd, Bonts I.td, and Tampax Ltd.

\section{References}

${ }^{1}$ Lippes, J, American Fournal of Obstetrics and Gynecology, 1965, 93, 1024. Fulton, D I, Hughes, R, and Neely, M R, Fournal of Obstetrics and Gynaecology of the British Commonwealth, i967, 74, 766.

${ }^{3}$ McCulloch, G, Medical fournal of Zambia, 1970, 4, 49.

+ Jones, R W, Parker, A, and Elstein, M, British Medical fournal, 1973, 3, 143.

Hallberg, L, and Nilsson, L, Scandinavian fournal of Clinical and Laboratory Investigation, 1964, 16, 244.

${ }^{6}$ Whitehouse, H B, Lancet, 1914, 1, 877

Rybo, G, Acta Obstetricia et Gynecologica Scandinavica, 1966, 45, 429.

$\checkmark$ Bonnar, J, and Allington, M, Paper read at VIII World Congress on Fertility and Sterility, Buenos Aires, Argentina, 5 November 1974.

\title{
Vitamin E deficiency and platelet functional defect in a jaundiced infant
}

\author{
M. KHURSHID, T. J. LEE, I. R. PEAKE, A. L. BLOOM
}

British Medical fournal, 1975, 4, 19-21

\section{Summary}

A 16-month-old infant with hepatic fibrosis, cholestasis, and chronic jaundice had signs of vitamin $E$ deficiency, including mild acanthocytosis, thrombocytosis, increased peroxide haemolysis, and absent serum vitamin $E$. Abnormal prothrombin consumption and platelet ristocetin aggregation suggested the presence of defective platelet function, and correction studies indicated that this was due to a plasma defect. The abnormality was corrected by treatment with vitamin $E$, and the findings suggest a possible role of this vitamin in platelet reactions.

\section{Introduction}

Little is known about the role of Vitamin $\mathrm{E}$ in thrombo poiesis or platelet function. High platelet counts are a recognized feature of vitamin $\mathrm{E}$ deficiency in premature infants and there is evidence suggesting that vitamin E may play a part in platelet aggregation induced by hydrogen peroxide.' We report here on an infant with hepatic fibrosis and cholestatic jaundice who developed vitamin E deficiency and impaired platelet function.

Department of Haematology, University Hospital of Wales, Cardiff CF4 4XW

M. KHURSHID, M.B., M.R.C.PATH., Senior Registrar (Present address Department of Haematology, Morriston Hospital, Swansea)

I. R. PEAKE, PH.D., Senior Scientific (Officer

A. L. BLOOM, M.D., M.R.C.PATH., Reader in Haematology

Department of Child Health, University Hospital of Wales, Cardiff CF4 4XW

T. J. LEE, M.B., M.R.C.P., Senior House Officer (Present address: Hospital for Sick Children, Great Ormond Street, London)

\section{Case Report}

A male infant weighing $3.55 \mathrm{~kg}$ was born by forceps delivery in May 1973 after a full-term pregnancy. The haemoglobin level at birth was $20.5 \mathrm{~g} / \mathrm{dl}$; his blood group was $\mathrm{B}+$; and the direct antiglobulin test on cord blood was negative. The mother was a primigravida, her blood group was $\mathrm{B}-$, but the antibody screen at 32 weeks' pregnancy gave negative results. The only medication received during pregnancy was oral iron.

Clinical examination of the infant at birth showed no abnormality. On day 2 twitching of face and limbs was noted. This subsided without treatment. On day 6 jaundice was noted. The serum bilirubin was $61.5 \mu \mathrm{mol} / 1,(3.6 \mathrm{mg} / 100 \mathrm{ml})$, serum aspartate aminotransferase (SGOT) $38 \mathrm{IU} / 1$, serum alanine amino-transferase (SGPT) $36 \mathrm{IU} / \mathrm{l}$, and serum alkaline phosphatase $55 \mathrm{IU} / 1$. On day 16 he was still jaundiced and the serum bilirubin was $46 \cdot 2 \mu \mathrm{mol} / \mathrm{l}(2.7 \mathrm{mg} / 100 \mathrm{ml})$. The Wasserman reaction and virus agglutination tests were negative. Sweat sodium concentration was $17 \mathrm{mmol} / 1$. The thyroid profile was normal. He was treated with prednisone $7.5 \mathrm{mg}$ every six hours but the jaundice persisted.

At six weeks he was transferred to the University Hospital of Wales. $\mathrm{He}$ was pale, feverish, and jaundiced with hepatomegaly but no splenomegaly. The urine was dark and stools pale but not completely colourless. Investigations showed: haemoglobin $11.9 \mathrm{~g} / \mathrm{dl}$, reticulocytes $3 \%$, platelets $699 \times 10^{\circ} / 1$, total bilirubin $85.5 \mu \mathrm{mol} / 1(5.0 \mathrm{mg} /$ $100 \mathrm{ml})$, conjugated bilirubin $17 \cdot 1 \mu \mathrm{mol} / 1(1 \mathrm{mg} / 100 \mathrm{ml})$, SGOT 126 IU/l, SGPT $158 \mathrm{IU} / 1$, and alkaline phosphatase $37 \mathrm{IU} / 1$. The urine contained no excess urobilinogen or bile salts. Serum immunoglobulins were normal. The Rose-Bengal excretion test showed that $18^{\prime \prime}$. was excreted in 48 hours and $21.6 \%$ in 72 hours. Though excretion was impaired it was more than that usually found in biliary astresia. Hepatitis was diagnosed and no specific treatment was recommended.

At 12 months his general condition remained the same but with slight clinical improvement; hepatomegaly of $1 \mathrm{~cm}$ persisted and he had developed pruritus. Serum bilirubin concentration was $58 \mu \mathrm{mol} / \mathbf{l}$ $(3.4 \mathrm{mg} / 100 \mathrm{ml})$, SGOT $274 \mathrm{IU} / \mathrm{l}$, alkaline phosphatase >150 IU/l, haemoglobin $10 \cdot 1 \mathrm{~g} / \mathrm{dl}$, and reticulocyte count $4 \%$. Oral iron treatment was begun and the haemoglobin rose to $11.0 \mathrm{~g} / \mathrm{dl}$. Because of the persistent jaundice laparotomy was considered for liver biopsy and the exclusion of biliary obstruction.

At 16 months, before laparotomy, several investigations were performed. Ultrasonic scan showed a normal gall bladder. Serum bilirubin concentration was $80.3 \mu \mathrm{mol} / 1(4.7 \mathrm{mg} / 100 \mathrm{ml})$, SGOT 247 $\mathrm{IU} / \mathrm{l}$, and alkaline phosphatase $160 \mathrm{IU} / 1$. Blood urea and electrolytes were normal. Tests for hepatitis-associated antigen and antibody 
were negative. Lipid studies showed serum cholesterol $7 \mathrm{mmol} / 1$ $(270 \mathrm{mg} / 100 \mathrm{ml})$ and triglycerides $4.3 \mathrm{mmol} / 1(381 \mathrm{mg} / 100 \mathrm{ml})$; lipoprotein electrophoresis showed an increase in the pre- $\beta$ region. The haemoglobin level was $11.0 \mathrm{~g} / \mathrm{dl}$, reticulocytes were $4 \%$, and platelets were $666 \times 10^{9} / 1$.

Tests of Haemostasis.-Though there was no clinical tendency to bleed tests of haemostasis were performed before surgery. Bleeding times (Ivy), clotting times (Lee and White), prothrombin times, kaolin-cephalin times, thrombin clotting times, prothrombin consumption index, fibrinogen titre tests, platelet factor 3 , and factor XIII tests were performed by standard techniques." Factor II was assayed by a two-stage method ${ }^{2}$ and factor VIII (coagulation) by the method of Pool and Robinson. ${ }^{3}$ Platelet adhesion was measured by a modification of the method of Bowie et $a l .{ }^{4}$ 'and aggregation by a method similar to that of Born." Immunological determination of factor VIII-related protein was performed on plasma by a modification of Laurell's method ${ }^{6}$ using plasma. ${ }^{7}$ The results are shown in the table. The only abnormalities in the routine tests were defective prothrombin consumption and thrombocytosis, which were both observed on several occasions. Coagulation factor assays were normal and the possibility of a platelet functional defect was considered. Platelet aggregation studies showed normal aggregation with adenosine diphosphate (ADP) $\left(3.5 \times 10^{-5} \mathrm{~mol} / \mathrm{l}\right)$, thrombin $(0.5 \mathrm{U} / \mathrm{ml})$, adrenaline $(25 \mu \mathrm{mol} / \mathrm{l} 4.6 \mathrm{mg} / \mathrm{l})$, and collagen, but defective aggregation with ristocetin at final concentrations of $1.0,1.2$, and $1.5 \mathrm{~g} / \mathrm{l}$. The levels of factor VIII by coagulation assay and of factor VIIIrelated protein were normal. The abnormal ristocetin aggregation was, however, fully corrected in vitro by the addition to the patient's platelet-rich plasma of cryoprecipitate or of a factor VIII-rich fraction prepared by gel filtration of cryoprecipitate ${ }^{8}$ and was partially corrected by normal platelet-poor plasma (see fig.).

\section{Results of Tests of Haemostasis Performed on Patient before Laparotomy}

\begin{tabular}{|c|c|c|}
\hline Test & Patient's Values & $\begin{array}{c}\text { Control } \\
\text { or Normal Values }\end{array}$ \\
\hline $\begin{array}{l}\text { Bleeding times }(\mathrm{min}) \\
\text { Clotting time }(\mathrm{min}) \\
\text { Platelet count }\left(\times 10^{\circ} / 1\right) \\
\text { Prothrombin time (one stage) (s) } \\
\text { Kaolin cephalin time }(\mathrm{s}) \\
\text { Thrombin clotting time (s) } \\
\text { Factor II ( }(\%) \\
\text { Factor VIII }(\%) \\
\text { Prothrombin consumption index }(\%) \\
\text { Factor VIII-related protein }(\%) \\
\text { Fibrinogen titre } \\
\text { Factor XIII screening test } \\
\text { (urea solubility) } \\
\text { Platelet adhesion }(\%) \\
\text { Platelet factor } 3 \text { activity }(\%)\end{array}$ & $\begin{array}{l}4 ! \\
7 ! \\
66 \\
666 \\
11 \cdot 0 \\
44 \cdot 5 \\
15 \cdot 5 \\
94 \\
108 \\
76 \\
119 \\
1 / 128 \\
\text { Normal } \\
48 \\
100\end{array}$ & $\begin{array}{l}<5 \\
5-10 \\
150-450 \\
12 \cdot 0 \\
42 \\
14 \cdot 5 \\
50-200 \\
50-200 \\
<20 \\
50-200 \\
1 / 32-1 / 128 \\
\text { Normal } \\
30-100 \\
>25\end{array}$ \\
\hline
\end{tabular}

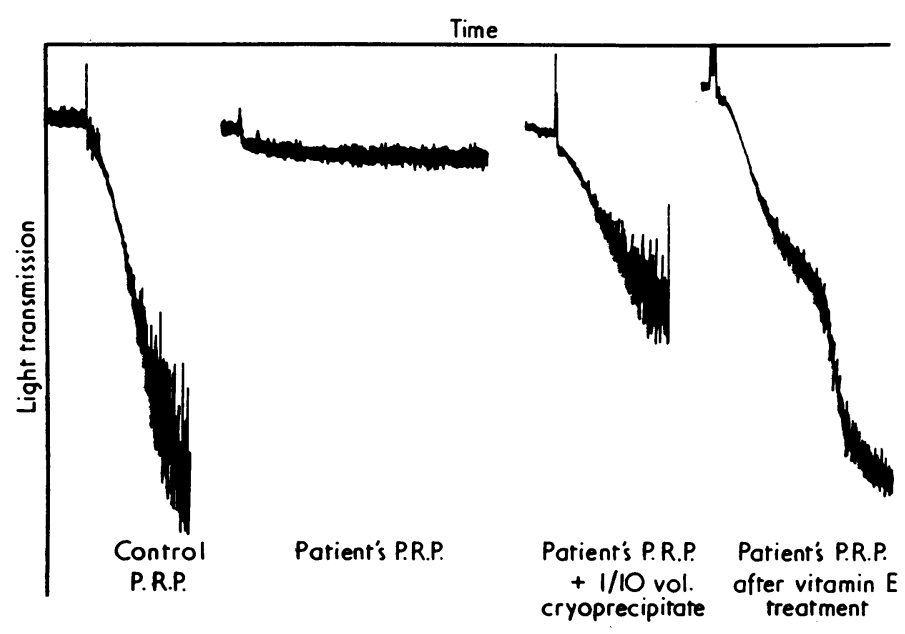

Platelet aggregation in patient's platelet-rich plasma (P.R.P.). Tracings show change of light transmission due to platelet aggregation with ristocetin $(1.5 \mathrm{~g} / \mathrm{l})$.

Tests of Vitamin E Status.-Examination of the peripheral blood film showed a few acanthocytic red cells and this, together with the high platelet count and chronic jaundice, suggested the possibility of vitamin $E$ deficiency. ${ }^{9} 10$ Red cell hydrogen peroxide fragility was assessed ${ }^{11}$ and was grossly abnormal-showing $90^{\circ}{ }^{\circ}$ haemolysis after 3 hours incubation (normal $<10^{\circ}{ }_{\circ}$ haemolysis). Serum vitamin $\mathrm{E}$ levels were assayed and no vitamin $\mathbf{E}$ was detected (normal adult level $>11.6 \mu \mathrm{mol} / \mathrm{l})(>500 \mu \mathrm{g} / 100 \mathrm{ml}))$. These findings confirmed a vitamin $\mathrm{E}$ deficiency. Bone marrow examination showed normal erythropoiesis, myelopoiesis, and megakaryocytes.

Progress.-Laparotomy was postponed and treatment begun with oral fat-soluble vitamin E (Ephynal) $10 \mathrm{mg} /$ day. After 18 days there was considerable clinical improvement and some relief of pruritis. Haemoglobin was $11.2 \mathrm{~g} / \mathrm{dl}$, platelets $592,10^{9} / 1$, and reticulocytes $3 \%$. The prothrombin consumption index reverted to normal $\left(7^{\circ}{ }_{0}\right)$, but platelet aggregation with ristocetin was still impaired. Hydrogen peroxide lysis was still abnormal with $90 \%$, haemolysis after three hours' incubation, but vitamin $\mathrm{E}$ could be detected in the patient's serum at $1.51 \mu \mathrm{mol} / 1(65 \mu \mathrm{g} / 100 \mathrm{ml}$ ) (as $\alpha$-tocopherol). At this stage treatment was changed to a water soluble $\alpha$-tocopherol-acetate preparation (supplied by Roche) $10 \mathrm{mg} /$ day. After a further 14 days the prothrombin consumption index remained normal and the platelets responded normally to ristocetin (see fig.), but the peroxide lysis test remained abnormal at $85^{\circ}$, haemolysis after incubation for three hours. Haemoglobin was $9.2 \mathrm{~g} / \mathrm{dl}$, platelets $551 \times 10^{9} / 1$, and reticulocyte count $1 \%$. Iron deficiency was confirmed by a serum iron level of $2.86 \mu \mathrm{mol} / 1(16.0 \mu \mathrm{g} / 100 \mathrm{ml})$ and total iron binding capacity of $128.88 \mathrm{umol} / \mathrm{l}(720 \mu \mathrm{g} / 100 \mathrm{ml})$. The vitamin E level was $1.69 \mu \mathrm{mol} / \mathrm{l}$ $(73 \mu \mathrm{g} / 100 \mathrm{ml})$.

Laparotomy.-Laparotomy was performed when all tests of haemostasis gave normal results. There was no excessive bleeding. No extrahepatic biliary obstruction was detected and liver biopsy showed hepatic fibrosis and cholestasis of undetermined type. The postoperative course was complicated by wound infection and intestinal obstruction but healing was complete in two weeks. Oral water soluble vitamin $\mathrm{E}$ ( $\alpha$-tocopherol acetate) treatment was restarted (10 $\mathrm{mg} /$ day), and phenobarbitone $15 \mathrm{mg}$ three times a day was given to attempt induction of hepatic enzymes.

One month after operation investigation showed bilirubin $85 \mu \mathrm{mol} / \mathrm{l}$, $(5.0 \mathrm{mg} / 100 \mathrm{ml})$, SGOT $48 \mathrm{IU} / \mathrm{l}$, and alkaline phosphatase $108 \mathrm{IU} / \mathrm{l}$. The prothrombin consumption index was normal, platelet aggregation studies remained normal, the serum vitamin $E$ level was $1.81 \mu \mathrm{mol} / \mathrm{l}$ $(78 \mu \mathrm{g} / 100 \mathrm{ml})$, and the peroxide cell lysis test was still abnormal at $90 \%$ lysis. Electron microscopic studies of platelets taken before and after treatment with $\alpha$-tocopherol showed normal platelet ultrastructure.

\section{Discussion}

The main haematological abnormalities first detected in this child were anaemia, thrombocytosis, and slight acanthocytosis. All these features have been described in the syndrome of vitamin $E$ deficiency in premature infants. ${ }^{9} 1 "$ Though the patient was not a premature infant subnormal levels of $\alpha$ tocopherol are also found in the serum of patients with steatorrhea and intrahepatic cholestasis. ${ }^{12}$ For these reasons the vitamin $E$ status of the child was investigated, and the studies confirmed the presence of severe vitamin $\mathrm{E}$ deficiency and enhanced peroxide red cell haemolysis.

The physiological role of vitamin $\mathrm{E}$ in humans is not very clear, but it may act as an antioxidant which prevents peroxidation of tissue lipids. ${ }^{13} 14$ Recent evidence has suggested that $\alpha$-tocopherol may have more specific effects on energy transfer reactions in liver microsomes or mitochondria ${ }^{15}$ and also in the regulation of porphyrin and haem metabolism. ${ }^{16}$ There is little knowledge on the relation between vitamin $\mathrm{E}$ and normal haemostasis. Such evidence that is available suggests that deficiency may be associated with a thrombotic tendency due to endothelial cell abnormalities ${ }^{17}$ and with thrombocytosis in premature infants, ${ }^{10}$ while it has been reported that hydrogen peroxide-induced platelet aggregation can be inhibited by vitamin $E$ derivatives. ${ }^{1}$ In our patient the abnormal prothrombin consumption in the presence of normal coagulation suggested defective platelet function, and this was supported by the impaired platelet aggregation with ristocetin. Impairment of platelet aggregation to ristocetin is seen as a primary platelet 
abnormality in the giant platelet syndrome of Bernard-Soulier ${ }^{18}$ and also in von Willebrand's disease, in which the abnormality is probably secondary to a deficiency or defect of a plasma protein related to factor VIII - the factor VIII-related protein. ${ }^{19}$ In our patient the defective ristocetin platelet aggregation seemed to be due to a plasma defect rather than to a primary platelet abnormality because aggregation was corrected partially or completely by the addition of normal plasma, cryoprecipitate, or a plasma fraction rich in factor VIII-related in protein. On the other hand the level of factor VIII-related protein in the infant's plasma was normal, which suggested that either there was a functional abnormality of this protein or the patient lacked another substance necessary for ristocetin platelet aggregation. This did not seem to be fibrinogen, which, it has been suggested, is a co-factor for ristocetin aggregation, ${ }^{20}$ because the thrombin clotting times and fibrinogen levels were normal. The small volumes of blood obtainable from the infant precluded more detailed in-vitro studies, and it is possible that the vitamin $E$ deficiency was directly responsible for the defective platelet ristocetin aggregation or that the deficiency resulted in the synthesis of an abnormal factor VIII-related protein. The normal bleeding time, the lack of family history, and the results of treatment, however, did not suggest that the infant was suffering from von Willebrand's disease.

The role of iron or folate deficiency in the pathogenesis of the patient's haematological status is difficult to assess. It has been suggested that folate deficiency may aggravate haemolysis in vitamin $\mathrm{E}$ deficiency, ${ }^{21}$ but though the patient's folate status was not certain his marrow was normoblastic, a finding which suggested that he did not have severe folate deficiency. Iron treatment is also thought to aggravate vitamin $\mathrm{E}$ deficiency and enhance lipid peroxidation and haemolysis, ${ }^{22}{ }^{23}$ but the child was not on iron treatment when his peroxide lysis tests gave persistently abnormal results. This persisting abnormality, however, was not really surprising because the serum vitamin $\mathrm{E}$ levels were not fully corrected with treatment. Though a relation between vitamin $\mathrm{E}$ deficiency and the abnormal platelet function was not definitely proved the response of the platelets to vitamin $\mathrm{E}$ treatment was striking. This finding suggests a possible relation between vitamin $\mathrm{E}$ and ristocetin-induced platelet aggregation which warrants further studies in patients in severe tocopherol-deficient states.

This patient was admitted under the care of Professor O. P. Gray to whom we are indebted for helpful comments and advice. We also thank Dr. J. F. Pennock of the biochemistry department at the University of Liverpool for the vitamin E assays. Mr. J. Lari performed the laparotomy.

\section{References}

${ }^{1}$ Higashi, O., Japanese fournal of Clinical Hematology, 1974, 14, suppl., p. 1372 .

2 Biggs, R., Human Blood Coagulation, Haemostasis and Thrombosis. Oxford, Blackwells Scientific Publications, 1972.

3 Pool, J. G., and Robinson, J., British fournal of Haematology, 1959, 5, 17.

${ }^{4}$ Bowie, E. J. W., et al., Mayo Clinic Proceedings, 1969, 44, 306.

${ }^{5}$ Born, G. V. R., Nature, 1962, 194, 927.

${ }^{6}$ Laurell, C.-B., Analytical Biochemistry, 1966, 15, 45.

' Bloom, A. L., Peake, I. R., and Giddings, J. C., Thrombosis Research, $1973,3,389$.

8 Peake, I. R., Bloom, A. L., and Giddings, J. C., New England fournal of Medicine, 1974, 291, 113.

9 Oski, F. A., and Barness, L. A., fournal of Pediatrics, 1967, 70, 211.

${ }^{10}$ Ritchie, J. H., et al., New England fournal of Medicine, 1968, 279, 1185.

${ }^{11}$ Horwitt, M. K., Vitamins and Hormones, 1962, 20, 541.

12 Binder, H. J., et al., New England fournal of Medicine, 1965, 273, 1289.

${ }^{13}$ Green, J., and Bunyan, J., Nutritional Abstracts and Reviews, 1969, 39, 321.

${ }^{14}$ Menzel, B. D., Jeffrey, N. R., and Lee, S. D., Agriculture and Food Chemistry, 1972, 20, 481.

15 Carabello, F. B., and Bird, J. W. C., Biochemical and Biophysical Research Communications, 1969, 34, 92.

16 Nair, P. P., and Pinelli, A., Giornale dell' Arteriosclerosi, 1969, 6, 339.

17 Nafstad, I., Thrombosis Research, 1974, 5, 257.

18 Howard, M. A., Hutton, R. A., and Hardisty, R. M., British Medical Journal, 1973, 4, 586.

19 Howard, M. A., and Firkin, B. E., Thrombosis et Diathesis Haemorrhagica, $1971,26,362$

${ }^{20}$ Baugh, R., et al., Biochemica et Biophysica Acta., 1974, 371, 360.

${ }^{21}$ Gross, S., American fournal of Clinical Nutrition, 1974, 27, 1130.

${ }^{22}$ Melhorn, D. K., Gross, S., and Childers, G., fournal of Paediatrics, 1971, 79, 569.

${ }^{23}$ Williams, M. L., et al., New England fournal of Medicine, 1975, 292, 887.

\section{SHORT REPORTS}

\section{Effect of ethamsylate and aminocaproic acid on menstrual blood loss in women using intrauterine devices}

The effect of ethamsylate and aminocaproic acid (EACA) in reducing menstrual bleeding were studied in women using intrauterine contraceptive devices (IUDs). Ethamsylate is claimed to increase capillary resistance and reduce menorrhagia by counteracting a fall in capillary resistance that occurs in the premenstrual phase. ${ }^{12}$ EACA is an antifibrinolytic agent which is believed to reduce menstrual blood loss by reducing the increase in endometrial fibrinolytic activity associated with menorrhagia. ${ }^{3}$

\section{Patients, methods, and results}

Twenty-five women complaining of excessive menstrual blood loss or volunteering for research while $\mathrm{t}$ sing IUDs were studied during six consecutive periods. The devices used were the Saf-T-Coil, Dalkon shield, Copper 7, and Lippes loop. By random allocation 12 patients received treatment during the third and fourth cycle with ethamsylate and 13 with EACA. One from each group did not complete the trial for personal reasons. A further patient from the EACA group dropped out after experiencing severe headache during treatment. Eleven women in each group completed the study. Blood loss was measured using the alkaline haematin method, which involved extracting iron pigment with $5 \% \mathrm{NaOH}$ from all sanitary towels used and measuring the optical density of the resulting solution. The accuracy of this method was $97 \%$. "Menstrual calendar" cards were also kept by each patient and all medicine taken was recorded. Ethamsylate was taken as tablets, $500 \mathrm{mg}$ four times a day from the onset of menstruation until bleeding ceased. EACA was taken as a powder dissolved in water, $3 \mathrm{~g}$ four times a day from the onset to the end of menstruation.

The results for both groups are summarised in the table. The average menstrual loss of $94.6 \mathrm{ml}$ in cycle 1 and $108.3 \mathrm{ml}$ in cycle 2 in the ethamsylatetreated group did not seem to be influenced by ethamsylate treatment in cycles 3 and 4, while treatment with EACA reduced menstrual loss by almost $50 \%$-a highly significant reduction $(P<0.001)$.

Mean $( \pm S D$ ) blood loss $(\mathrm{ml})$ in 11 women treated with ethamsylate and 11 treated with $E A C A$ in cycles 3 and 4

\begin{tabular}{|c|c|c|c|c|c|c|c|}
\hline Period: & 1 & 2 & 3 & 4 & 5 & 6 & $\begin{array}{l}\text { P Values } \\
\text { (log } \\
\text { values)* }\end{array}$ \\
\hline $\begin{array}{l}\text { Ethamsylate } \\
\text { group } \\
\text { EACA group }\end{array}$ & $\begin{array}{r}94.6 \\
\pm 73.6 \\
132.3 \\
\pm 102.3\end{array}$ & $\begin{array}{r}108.3 \\
\pm 91.2 \\
122.9 \\
\pm 91 \cdot 3\end{array}$ & $\begin{array}{r}94 \cdot 3 \\
\pm 89.6 \\
59.8 \\
\pm 46.7\end{array}$ & $\begin{array}{r}100.9 \\
\pm 85.4 \\
54.0 \\
\pm 28.7\end{array}$ & $\begin{array}{r}100.9 \\
+85.4 \\
121.0 \\
+117.5\end{array}$ & $\begin{array}{r}109.5 \\
\pm 110.9 \\
109.4 \\
\pm 106.4\end{array}$ & $\begin{array}{l}0.7 \\
0.001\end{array}$ \\
\hline
\end{tabular}

*In view of the skewed distribution of data all results were converted to logarithms before applying Student's $t$ test for significance. 